\title{
有限な薄水盤に囲まれた固定式中空円筒構造物の地震流力弾性解析 SEISMIC HYDROELASTICITY FOR FIXED HOLLOW CYRINDRICAL STRUCTURES SURROUNDED BY THIN ICE SHEET OF FINITE WIDTH
}

\author{
濱本卓司*, 大西弘亮**, 井上昌士*** \\ Takuji HAMAMOTO, Hiroaki OONISHI and Masashi INOUE
}

\begin{abstract}
The hydroelastic response of fixed hollow cylindrical structures surrounded by thin floating ice sheet of finite width during earthquakes is formulated. The elastic shell theory is used for structures, whereas the potential flow theory is applied to fluid domain. The sea ice is idealized as the annular rigid boundary that is connected with semi-infinite free surface. The hydrodynamic pressure is obtained in closed form by domain division method. Wet mode properties in beam mode of hollow cylindrical structure are evaluated by Rayleigh-Ritz method. Modal superposition approach is used to calculate the earthquake response against horizontal ground motion. Numerical examples are presented to illustrate the changes in hydrodynamic pressures and earthquake responses due to the width of ice sheet.
\end{abstract}

Keywords : Sea ice, Earthquake response, Hydroelasticity, Domain division method, Circular cylindrical shell, Rayleigh-Ritz method

海水, 地震応答, 流力弾性, 領域分割法, 円筒シェル, レーリー・リッツ法

\section{1. 序}

日本近海の水海域はオホーツク海である。オホーツク海の海水は 12 月初旬に北西部から結水し，徐々に成長して 1 月中旬には北海道 に達する。さらに 3 月中旬から下旬にかけて最も成長し，オホーツ ク海の $80 \%$ が水で覆われる。その後，徐々に後退を始め 6 月には消 滅する。したがって，オホーツク海は氷海域といっても，一年の半 分は無水状態, 後の半分が海水状態である1。海水状態は多様で, 結 水，破砕水，堆積水，流水など様々であり，さらに各状態は水の厚 さや広がりにより細かく分類することができる。

氷海域に建設される構造物は，このような様々な海水状態におけ る氷荷重に対して十分な抵抗力を有している必要があり，すでに設 計規準や指針も整備されている ${ }^{2,3)}$ 。また，氷荷重に対する構造物の 静的・動的応答に関する研究もロシア，カナダ，フィンランド，ア メリカなどで活発に行われている ${ }^{4,5)}$ 。しかし, 水海域に扔ける地震 荷重の検討はまだ十分とはいえない。

オホーツク海中央部の地震活動度は低いが，オホーツク海の東西 縁はそれぞれ太平洋プレートと北米プレートの境界および北米プ レートとユーラシアプレートの境界になっており地震活動度が高 い6)。このため，オホーツク海に構造物を建設するには，水荷重の検 討だけでなく，地震時の構造物の応答挙動を適切に予測し構造物の 臫震安全性を確保することが必要になる。最近のオホーツク海サ八 リン沖の海底油田開発にともない，わが国でも氷海構造物に関する

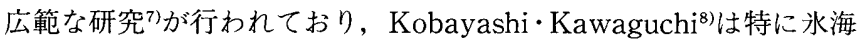
構造物の地震応答に関する研究のレビューを行っている。

氷海域における構造物の地震応答挙動を予測するには, 水が構造

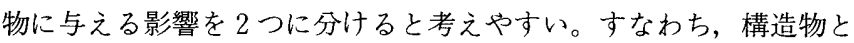

水の相互作用効果と氷の存在による地震荷重の増幅効果である。構 造物と水の相互作用を検討するには，まず構造物と水の力学特性を 把握する必要がある9,10)。特に, 水の力学特性は様々な環境要因によ り複雑に変化する。このような場合, 水の影響を構造物へのばね効 果や質量効果に集約してモデル化することが有効である ${ }^{11,12) 。 し か ~}$ し, 氷のばね効果や質量効果は両者が接触しているという条件のも とで生じる。オホーツク海の氷は一年水であり，北極海における多 年水のように水が厚く成長することはなく，水厚はオホーツク海北 部で約 $1 \mathrm{~m}$, 北海道付近で約 $0.5 \mathrm{~m}$ と比較的薄い。このように氷盤が薄 い場合には, 構造物周辺が結水していたとしても,地震が発生すると 水は破壊し, 氷盤のばね効果や質量効果は消失する可能性が大きい。

一方, 海水が海面を覆っていると, 地震時に水の下の海水領域に 発生する動水圧を閉じこめ増大させるが，この影響は氷盤の厚さに 関わらず無視できない。清川 ${ }^{13)}$ は剛体円筒構造物を対象に, 海面の全 領域が結水した場合の水平地震動に対する動水圧を解析的に求め た。濱本ら ${ }^{14)}$ は弾性中空円筒構造物を対象に, 海面の全領域が結水し た場合の水平地震動に対する動水圧を解析的に求め地震応答挙動 の影響を検討した。森田ら ${ }^{15)}$ は水盤を有限な弾性体としてモデル化 し，剛体軸対称構造物に作用する動水圧を数值解析により求めた。 しかし，弾性構造物の周囲に有限な水盤があるときに生じる動水圧 の閉じ込め効果に関する検討はほとんど行われていない16)。

本研究は，オホーツク海のような一年氷の水海域に建設される固 定式中空円筒構造物の地震時流力弾性挙動を予測するための解析的 アプローチを示したものである。水盤のばね効果や質量効果が無視 できる薄氷盤を対象とし，有限の広がりを有する氷盤を等価な円環 形状と見なすなどの仮定をおいているが，モデル化された世界の中
$*$ 武蔵工業大学工学部建築学科 教授・工博

***清水建設 修士 (工学)

*** 日本設計 修士 (工学)
Prof., Dept. of Architecture, Musashi Institute of Technology, Dr. Eng. Shimizu Corp., M. Eng. Nihon Sekkei, M. Eng. 
では厳密な数理展開を行っている。構造物には弾性シェル理論, 海 水領域には線形ポテンシャル理論を適用する。水盤のある海面を剛 体境界, 水盤のない海面を自由表面境界とする混合境界值問題とし て定式化し，構造物に作用する動水圧を領域分割法により解析的に 導く。レーリー・リッツ法により梁モードのウェットモード特性を 評価した後, モード合成法により水海域における水平地震動に対す る動水圧分布と応答挙動を予測する。数值例題により, 海水がある 場合とない場合の動水圧と地震応答の違いを明らかにするととも に，周囲の水盤の広がりが地震応答に与える影響を検討する。

\section{2. 解析モデルと仮定}

有限な広がりを有する海水に囲まれた固定式中空円筒構造物を Fig. 1に示す。構造物の高さを $l$, 半径を $a$, 厚さを $h$, 設置水樑を $d$ とする。海水の閉じ込好効果による動水圧への影響を検討するとい う観点から, 水盤を構造物に隣接する厚さのない幅 $b-a$ の円環 $(h$ 《b) としてモデル化している。地震動として海底面の水平動を考 之，その地盤変位を $U_{g}$, 構造物の面外変形を $w$ とす。

本研究で導入する仮定を列記する。

1) 構造物の地震応答は線形振動の範囲内である。

2) 構造物の応力一Uずみ関係は線形シェル理論に従う。

3 ）海水は構造物を円環状に囲む風体と見なすことができる。

4 ）水盤は薄くその厚さは無視できる。

5 ）地震が発生すると構造物周辺の水盤は破壊し, 水盤のばね効果 と質量効果は無視できる。

6 ）構造物周辺の水盤の破壊による動水圧の消散効果は無視できる。

7 ）海水は非粘性・非圧縮性・渦なしである。

8 ）水深は一定で海水は水平方向に無限に広がっている。

9）海底は風であり，海底地盤との相互作用は無視できる。

10）地震動は水平成分のみを考之，その定常部の加速度パワースペ クトルは修正金井・田治見式で与えられる。

\section{3. 地震荷重}

水平地震動を受けると中空円筒構造物は剛体運動と面内および面 外の弾性変形で応答する。海底が剛であれば励起される弾性変形は

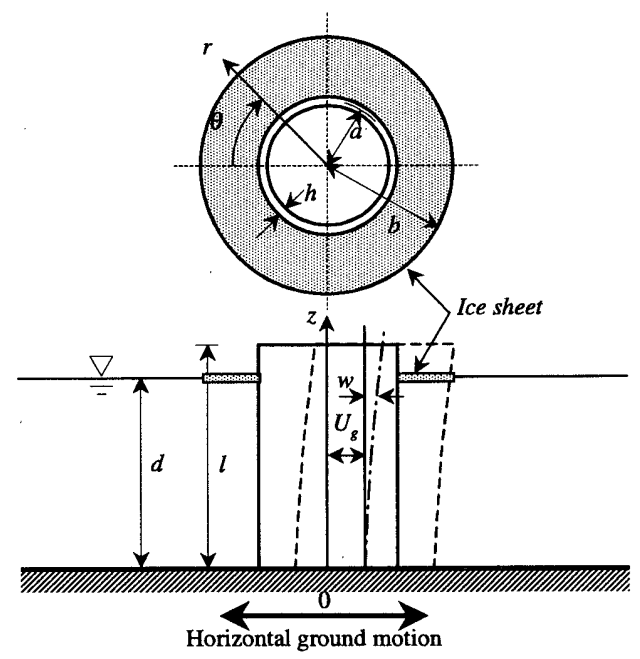

Fig. 1 Analytical model of hollow cylindrical structure subjected to horizontal ground motion in ice-covered seas
梁モード (円周方向波数 $n=1$ ) のみである。このとき構造物には水 平剛体運動による構造物の慣性力が作用する。Fig. 2(a)に示すよう に, 点 $(a, \theta, z)$ に作用する慣性力の軸方向, 円周方向, および半 径方向成分はそれぞれ以下のように与えられる。

$$
\begin{aligned}
& p_{z}=0, \\
& p_{\theta}=-\rho_{s} h \sin \theta \cdot \ddot{U}_{g}, \\
& p_{r}=\rho_{s} h \cos \theta \cdot \ddot{U}_{g},
\end{aligned}
$$

ここに， $\rho_{s}$ は構造物の質量密度， $\ddot{U}_{g}$ は水平地盤加速度である。

構造物の外面には常に静水圧が作用しているが，地震時にはさら に Fig. 2(b)に示すように動水圧 $p_{w}$ が半径方向に作用する。

$$
p_{\mathcal{W}}=p_{R}+p_{E}
$$

ここに, $p_{R}$ は水平剛体運動により生じる動水圧， $p_{E}$ は面外弾性変 形により生じる動水圧である。

構造物の慣性力と海水の動水圧の和が構造物に作用する地震力と なる。動水圧は海面を覆う氷盤の影響を受ける。水盤の幅 $b-a$ が 0 であれば海面は全領域で自由表面となり, 従来の海洋構造物の地震 応答解析と同じである。氷盤の幅が大きくなるにつれて動水圧の閉 じ込め効果は増加し，海面が全領域で剛体境界となったときの動水 圧の值に徐々に収束すると予想される。水盤の幅は動水圧の大きさ だけでなく分布形にも影響を与える。

\section{4. 動水圧の誘導}

水平地震動が作用するとき中空円筒構造物の外面に生じる動水圧 分布をポテンシャル流れ理論により求める。水の状態として, 無水 状態，全水状態，部分水状態を考之る。部分水状態における水盤の 幅 $b-a$ が 0 のそ無水状態， $\infty$ とき全水状態となる。

海水領域の速度ポテンシャルを以下のように表す。

$$
\Phi(r, \theta, z, t)=\phi(r, \theta, z) \exp (i \sigma t)
$$

ここに, $\phi(r, \theta, z)$ は速度ポテンシャルの空間項, $\exp (i \sigma t)$ は時間 項, $i=\sqrt{-1}, \sigma$ は円振動数， $t$ は時間である。

\section{4-1 無水状態}

海面に氷盤が全く存在しない無水状態のとき，海面は全流体領域 で自由表面境界となる。無水状態の速度ポテンシャルの空間項に関 する境界值問題は以下のように与えられる (Fig. 3参照)。

$$
\begin{array}{ll}
\nabla^{2} \phi=0 & : 0 \leq z \leq d, \\
\frac{\partial \phi}{\partial z}-\frac{\sigma^{2}}{g} \phi=0 & : z=d, \\
\frac{\partial \phi}{\partial z}=0 & : z=0, \\
\frac{\partial \phi}{\partial r}=\dot{W} & : r=a,
\end{array}
$$




$$
\lim _{r \rightarrow \infty} \sqrt{r}\left(\frac{\partial \phi}{\partial r}+i k \phi\right)=0 \quad: r \rightarrow \infty,
$$

ここに, $g$ は重力加速度, $W=U_{g}+w$ は構造物の面外変位, $k$ は 波数,・=d/dtである。式(4a)は非粘性, 非圧縮性, 渦なしの流体場を 支配するラプラス方程式, 式(4b)は海面における自由表面境界条件, 式(4c)は海底面における剛体境界条件, 式(4d)は構造物と海水の運動 の連続条件，式(4e)は放射条件である。

式(4a e)を満足する無氷状態の速度ポテンシャルの空間項 $\phi の$ 解 は次式で与えられる ${ }^{17) 。 ~}$

$$
\begin{aligned}
\phi= & 4 i \sigma \sum_{n=0}^{\infty}\left\{\frac{H_{n}^{(2)}(k r)}{H_{n}^{(2)}(k a)} \frac{\int_{0}^{d} W_{n}(z) \cosh k z d z}{\sinh 2 k d+2 k d} \cosh k z\right. \\
& \left.+\sum_{s=1}^{\infty} \frac{K_{n}\left(k_{s} r\right)}{K_{n}^{\prime}\left(k_{s} a\right)} \frac{\int_{0}^{d} W_{n}(z) \cos k_{s} z d z}{\sin 2 k_{s} d+2 k_{s} d} \cos k_{s} z\right\} \cos n \theta,
\end{aligned}
$$

ここに, $W_{n}(z)$ は円周方向フーリエ波数 $n$ における面外変位成分 $W$ の軸方向関数, $K_{n}(x)$ は $n$ 位の第 2 種変形ベッセル関数, $H_{n}^{(2)}(x)$ は $n$ 位の第 2 種ハンケル関数，'は は $\partial / \partial(k r)$ あるいは $\partial / \partial\left(k_{s} r\right), k$ と ksは次式で与えられる超越方程式を満足する波数である。

$$
\sigma^{2}=k g \tanh k d=-k_{s} g \tan k_{s} d .
$$

\section{4-2 全水状態}

海面が氷盤により完全に覆い尽くされる全水状態のとき，海面は 全流体領域で岡体境界となる。全水状態の速度ポテンシャルの空間 項に関する境界值問題は以下のように与えられる。

$$
\begin{array}{ll}
\nabla^{2} \phi=0 & : 0 \leq z \leq d, \\
\frac{\partial \phi}{\partial z}=0 & : z=d, \\
\frac{\partial \phi}{\partial z}=0 & : z=0, \\
\frac{\partial \phi}{\partial r}=\dot{W} & : r=a, \\
\phi \rightarrow 0 & : r \rightarrow \infty,
\end{array}
$$

ここに, 式(7b)は海面における剛体境界条件, 式(7e)は遠方での減衰 条件である。

式(7a e)を満足する全水状態の速度ポテンシャルの空間項 $\phi$ の解 は次式で与えられる14)。

$$
\begin{array}{r}
\phi=i \sigma \sum_{n=0}^{\infty}\left\{-\frac{a}{n}\left(\frac{a}{r}\right)^{n} \frac{\int_{0}^{d} W_{n}(z) d z}{d}+2 \sum_{s=1}^{\infty} \frac{K_{n}\left(l_{s} r\right)}{K_{n}^{\prime}\left(l_{s} a\right)}\right. \\
\left.\cdot \frac{\int_{0}^{d} W_{n}(z) \cos l_{s} z d z}{l_{s} d} \cos l_{s} z\right\} \cos n \theta,
\end{array}
$$

ここに, $l_{s}=s \pi / d(s=1,2,3 \cdots), \quad '=\partial / \partial\left(l_{s} r\right)$ である。

\section{4-3 部分氷状態}

構造物周辺の一部の海面が氷盤で覆われる部分水状態のとき，海 面には剛体境界と自由表面境界が同時に存在する。このときの解を 領域分割法により以下に解析的に導く。部分水状態の速度ポテン シャルに関する境界値問題は, Fig. 3に示すように, 剛体境界下の近 傍領域と自由表面境界下の遠方領域に流体領域を分割し，各領域の 速度ポテンシャルの空間項をそれぞれ $\phi_{i}$ (添字 $i$ は ice を表わす) と $\phi_{f}$ (添字 $f$ は free を表わす) とおくことにより以下のように与えられる。 剛体境界下の近傍領域では,

$$
\nabla^{2} \phi_{i}=0
$$$$
: 0 \leq z \leq d,
$$

$$
\begin{array}{ll}
\frac{\partial \phi_{i}}{\partial z}=0 & : z=d, \\
\frac{\partial \phi_{i}}{\partial z}=0 & : z=0, \\
\frac{\partial \phi_{i}}{\partial r}=\dot{W} & : r=a,
\end{array}
$$

自由表面境界下の遠方領域では，

$$
\begin{array}{ll}
\nabla^{2} \phi_{f}=0 & : 0 \leq z \leq d, \\
\frac{\partial \phi_{f}}{\partial z}-\frac{\sigma^{2}}{g} \phi_{f}=0 & : z=d, \\
\frac{\partial \phi_{f}}{\partial z}=0 & : z=0, \\
\lim _{r \rightarrow \infty} \sqrt{r}\left(\frac{\partial \phi_{f}}{\partial r}+i k \phi_{f}\right)=0 & : r \rightarrow \infty .
\end{array}
$$

式 $(9 \mathrm{a} \sim \mathrm{c})$ を満足する近傍領域の速度ポテンシャルの空間項 $\phi_{i}$ は次 式で与えられる。

$$
\begin{aligned}
\phi_{i}= & \sum_{n=0}^{\infty}\left[B_{n 0}\left(\frac{b}{r}\right)^{n}+C_{n 0}\left(\frac{r}{b}\right)^{n}\right. \\
& \left.+\sum_{s=1}^{\infty}\left\{B_{n s} \frac{K_{n}\left(l_{s} r\right)}{K_{n}\left(l_{s} b\right)}+C_{n s} \frac{I_{n}\left(l_{s} r\right)}{I_{n}\left(l_{s} b\right)}\right\} \cos l_{s} z\right] \cos n \theta,
\end{aligned}
$$

ここに， $B_{n 0}, C_{n 0}, B_{n s}, C_{n s}$ は未定係数, $l_{s}=s \pi / d(s=1,2,3 \cdots)$, $I_{n}(x)$ は $n$ 位の第 1 種変形ベッセル関数である。

式(11)を式(9d)に代入し，区間 $[0, d]$ で積分すると次式を得る。

$$
-B_{n 0} \frac{n}{b}\left(\frac{b}{a}\right)^{n+1}+C_{n 0} \frac{n}{b}\left(\frac{b}{a}\right)^{n-1}=\frac{i \sigma}{d} \int_{0}^{d} W_{n}(z) d z .
$$

式(11)を式(9d)に代入し，両辺に $\cos l_{s} z$ を乗じ区間 $[0, d]$ で積分する と次式を得る。

$$
B_{n s} \tilde{K}_{n s}+C_{n s} \tilde{I}_{n s}=i \sigma \frac{2}{d} \int_{0}^{d} W_{n}(z) \cos l_{s} z d z,
$$

ここに，

$$
\tilde{K}_{n s}=\frac{K_{n}^{\prime}\left(l_{s} a\right)}{K_{n}\left(l_{s} b\right)}, \quad \tilde{I}_{n s}=\frac{I_{n}^{\prime}\left(l_{s} a\right)}{I_{n}\left(l_{s} b\right)},
$$

である。

式(10a d を満足する遠方領域の速度ポテンシャルの空間項 $\phi_{f}$ は 次式で与えられる。

$\phi_{f}=\sum_{n=0}^{\infty}\left\{D_{n 0} \frac{H_{n}^{(2)}(k r)}{H_{n}^{(2)}(k b)} \cosh k z+\sum_{l=1}^{\infty} E_{n l} \frac{K_{n}\left(k_{l} r\right)}{K_{n}\left(k_{l} b\right)} \cos k_{l} z\right\} \cos n \theta$, (15) ここに， $D_{n 0}$ と $E_{n l}$ は未定係数である。

近傍領域と遠方領域の接続条件は以下のように与えられる。

$$
\begin{array}{ll}
\frac{\partial \phi_{i}}{\partial r}=\frac{\partial \phi_{f}}{\partial r} & : r=b, 0 \leq z \leq d, \\
\phi_{i}=\phi_{f} & : r=b, 0 \leq z \leq d,
\end{array}
$$

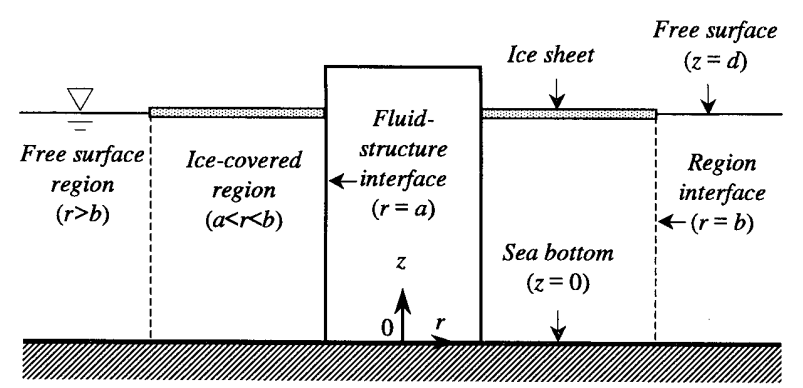

Fig. 3 Domain division method 
ここに, 式(16a)は速度ポテンシャルの半径方向微分の接続条件(物 理的には海水の運動の連続条件), 式(16b)は速度ポテンシャルの接続 条件（物理的には圧力の連続条件）である。

式(11)と式(15)を式(16a)に代入し，両辺に $\cosh k z$ を乗じ $z$ に関して区 間 $[0, d]$ で積分すると次式を得る。

$$
\left\{-B_{n 0}+C_{n 0}\right\} d_{n}+\sum_{s=1}^{\infty}\left\{B_{n s} \bar{K}_{n s}+C_{n s} \bar{I}_{n s}\right\} S_{n s}=D_{n 0} \bar{H}_{n} b_{n},
$$

$$
\text { ここに, }
$$$$
b_{n}=\frac{1}{4 k}\{\sinh 2 k d+2 k d\},
$$

$d_{n}=\frac{n}{b k} \sinh k d$,

$$
S_{n s}=\frac{k}{l_{s}^{2}+k^{2}} \sinh k d \cos s \pi
$$

$$
\bar{K}_{n s}=\frac{K_{n}^{\prime}\left(l_{s} b\right)}{K_{n}\left(l_{s} b\right)} l_{s}, \quad \bar{I}_{n s}=\frac{I_{n}^{\prime}\left(l_{s} b\right)}{I_{n}\left(l_{s} b\right)} l_{s}, \quad \bar{H}_{n}=\frac{H_{n}^{(2)}(k b)}{H_{n}^{(2)}(k b)} k, \quad(18 \mathrm{~d}, \mathrm{e}, \mathrm{f})
$$

である。

式(11)と式(15)を式(16a)に代入し，再辺に $\cos k_{i} z$ を乗じ $z$ に関して区 間 $[0, d]$ で積分すると次式を得る。

$$
\begin{aligned}
&\left\{-B_{n 0}+C_{n 0}\right\} d_{n l}+\sum_{s=1}^{\infty}\left\{B_{n s} \bar{K}_{n s}+C_{n s} \bar{I}_{n s}\right\} S_{n l}=E_{n l} \bar{K}_{n l} b_{n l}, \\
& \text { ここに, }
\end{aligned}
$$

$$
\begin{aligned}
& b_{n l}=\frac{1}{4 k_{l}}\left\{\sin 2 k_{l} d+2 k_{l} d\right\}, \\
& d_{n l}=\frac{n}{b k_{l}} \sin k_{l} d, \\
& S_{n s l}=\frac{k_{l}}{k_{l}^{2}-l_{s}^{2}} \sin k_{l} d \cos s \pi, \\
& \bar{K}_{n l}=\frac{K_{n}^{\prime}\left(k_{l} b\right)}{K_{n}\left(k_{l} b\right)} k_{l},
\end{aligned}
$$

である。

式(11)と式(15)を式(16b)に代入し， $z$ に関して区間 $[0, d]$ で積分すると 次式を得る。

$$
\begin{aligned}
& \left\{B_{n 0}+C_{n 0}\right\} d=D_{n 0} f_{n}+\sum_{l=1}^{\infty} E_{n l} \frac{b}{n} d_{n l}, \\
\text { ここに, } & \\
& f_{n}=\frac{1}{k} \sinh k d,
\end{aligned}
$$

である。

式(11)と式(15)を式(16b)に代入し，両辺に $\cos l_{s} z$ を乗じ, $z$ に関して区 間 $[0, d]$ で積分すると次式を得る。

$$
\sum_{s=1}^{\infty}\left\{B_{n s}+C_{n s}\right\} \frac{d}{2}=S_{n s} D_{n 0}+\sum_{l=1}^{\infty} E_{n l} S_{n s t} .
$$

式(12)，(13)，(17)，(19)，(21)，(23)は未定係数 $B_{n s}, C_{n s}(s=0,1,2 \cdots) ， D_{n 0}$, $E_{n l}(l=1,2, \cdots)$ に関する無限個の連立方程式を構成する。実際に連 立方程式を解くためには, $s$ とを適当な項数で打ち切る必要がある。 本研究では，収束性を確認し項数はともに20とした。未定係数を決 定することにより内部および外部領域の速度ポテンシャルが求まる。

速度ポテンシャルが求まれば，構造物に作用する動水圧 $p_{w}$ は以 下のベルヌーイ式により与えられる。

$$
p_{w}=-\rho_{w} \frac{\partial \Phi_{i}}{\partial t}, \quad: r=a,
$$

ここに, $\rho_{w}$ は海水の質量密度, $\Phi_{i}=\phi_{i}(r, \theta, z) \exp (i \sigma t)$ は近傍領域 の速度ポテンシャルである。

\section{5. 自由振動解析}

地震動による荷重項，すなわち剛体運動による慣性力と動水圧を 0 とおき, 静稳な水海域におけるウェットモード自由振動解析を Rayleigh-Ritz 法により定式化する。水平地震動のときは梁モード のみが励起されるのでウェットモード自由振動解析もこのモードの みに対して行う。

中空円筒構造物の梁モード $(n=1)$ の弾性変形を軸方向, 円周方 向，および半径方向変位成分により以下のように表す ${ }^{17) 。 ~}$

$$
\begin{aligned}
& u=\sum_{j=1}^{N} U_{m 1 j} g_{j}(z) \cos \theta \exp \left(i \omega_{m 1} t\right), \\
& v=\sum_{j=1}^{N} V_{m 1, j} f_{j}(z) \sin \theta \exp \left(i \omega_{m 1} t\right), \\
& w=\sum_{j=1}^{N} W_{m 1 j} f_{j}(z) \cos \theta \exp \left(i \omega_{m 1} t\right),
\end{aligned}
$$

ここに，Nは級数の重ね合わせ数, 添字 $m$ は軸方向モード次数, $\omega_{m 1}$ は $m 1$ 次ウェットモード円振動数, $g_{j}(z)$ と $f_{j}(z)$ はそれぞれ以下 に示す空中における片持梁の軸方向振動と曲げ振動の $j$ 次正規関数 である。

$$
g_{j}(z)=\sin \frac{(2 j-1) \pi}{2 l} z,
$$

$f_{j}(z)=\cosh \alpha_{j} z-\cos \alpha_{j} z-c_{j}\left(\sinh \alpha_{j} z-\sin \alpha_{j} z\right)$,

ここに,

$c_{j}=\left(\sinh \alpha_{j} l-\sin \alpha_{j} l\right) /\left(\cosh \alpha_{j} l+\cos \alpha_{j} l\right)$

であり， $\alpha_{j} l$ は次式で与えられる超越方程式を満足する。

$\cosh \alpha_{j} l \cos \alpha_{j} l+1=0$.

一般化座標に $U_{m 1 j}(t)=U_{m 1 j} \exp \left(i \omega_{m 1} t\right), \quad V_{m 1 j}(t)=V_{m 1 j} \exp$ $\left(i \omega_{m 1} t\right)$ ，および $W_{m 1 j}(t)=W_{m 1 j} \exp \left(i \omega_{m 1} t\right)$ を選ぶと，中空円筒構造 物の運動は以下のラグランジェ方程式に支配される。

$$
\frac{d}{d t}\left(\frac{\partial T}{\partial \dot{U}_{m 1 j}}\right)-\frac{\partial T}{\partial U_{m 1 j}}+\frac{\partial S}{\partial U_{m 1 j}}=0
$$

$$
\frac{d}{d t}\left(\frac{\partial T}{\partial \dot{V}_{m 1 j}}\right)-\frac{\partial T}{\partial V_{m 1 j}}+\frac{\partial S}{\partial V_{m 1 j}}=0
$$

$$
\frac{d}{d t}\left(\frac{\partial T}{\partial \dot{W}_{m 1 j}}\right)-\frac{\partial T}{\partial W_{m 1 j}}+\frac{\partial S}{\partial W_{m 1 j}}=Q_{m 1 j},
$$

ここに，SとTはそれぞれ構造物のUずみエネルギーと運動エネ ルギーであり, 薄肉シェル理論に基づき以下のように与えられる

$$
\begin{aligned}
S= & \frac{E h}{2\left(1-\mu^{2}\right)} \int_{0}^{l} \int_{0}^{2 \pi}\left[\left(\frac{\partial u}{\partial z}\right)^{2}+\frac{1}{a^{2}}\left(\frac{\partial v}{\partial \theta}+w\right)^{2}+\frac{a}{2 \mu} \frac{\partial u}{\partial z}\left(\frac{\partial v}{\partial \theta}+w\right)\right. \\
& +\frac{1}{2}(1-\mu)\left(\frac{\partial v}{\partial z}+\frac{1}{a} \frac{\partial u}{\partial \theta}\right)^{2}+\frac{h^{2}}{12 a^{2}}\left\{a^{2}\left(\frac{\partial^{2} w}{\partial z^{2}}\right)^{2}\right. \\
& +\frac{1}{a^{2}}\left(\frac{\partial^{2} w}{\partial \theta^{2}}-\frac{\partial v}{\partial \theta}\right)^{2}+2 \mu \frac{\partial^{2} w}{\partial z^{2}}\left(\frac{\partial^{2} w}{\partial \theta^{2}}-\frac{\partial v}{\partial \theta}\right) \\
& \left.\left.+2\left(1-\mu^{2}\right)\left(\frac{\partial^{2} w}{\partial z \partial \theta}-\frac{\partial v}{\partial z}\right)^{2}\right\}\right] a d \theta d z,
\end{aligned}
$$

$T=\frac{\rho_{s} h}{2} \int_{0}^{l} \int_{0}^{2 \pi}\left[\left(\frac{\partial u}{\partial t}\right)^{2}+\left(\frac{\partial v}{\partial t}\right)^{2}+\left(\frac{\partial w}{\partial t}\right)\right] a d \theta d z$,

ここに, Eは構造物のヤング係数, $\mu$ はポアソン比, $\rho_{s}$ は質量密度 である。式(29c)の右辺の $Q_{m 1 j}$ は一般化力であり次式で与えられる。 


$$
Q_{m 1 j}=\int_{0}^{d} \int_{0}^{2 \pi} p_{w} \cdot f_{j}(z) \cos \theta a d \theta d z,
$$

式(25a〜c)を式(30a, b) に代入し，その結果を式(29a c)に代入した後, 正規関数の直交性を利用すると, 静穞な水海域で自由振動する構造 物の運動方程式が以下のマトリックス式として得られる。

$\left\{[K]-\Delta\left([M]+\left[M_{W}\right]\right)\right\}\{\delta\}=0$,

ここに, $[K],[M]$, および $\left[M_{W}\right]$ は構造物の岡性マトリックス $(3 N$ $\times 3 N)$ ，質量マトリックス $(3 N \times 3 N)$ ，および構造物と海水の相互 作用による付加質量マトリックス $(3 N \times 3 N),\{\delta\}=\{U|V| W\}^{T}$ は モード振幅べクトル $(3 N \times 1)$ で，\{U\}，\{V\}，および $\{W\}$ はぞれぞ れ $U_{m 1 j}, V_{m 1 j}$, および $W_{m 1 j}$ を成分とするべクトル $(N \times 1), \Delta=\rho_{s} \omega_{m 1}^{2}$ $\left(1-\mu^{2}\right) a^{2} / E$ は振動数パラメータである。

式(32)の振動数方程式は次式で与えられる。

$$
\left|[K]-\Delta\left([M]+\left[M_{W}\right]\right)\right|=0,
$$

上式を解くことによりウェットモード振動数とモード形が求まる。

\section{6. 地震応答解析}

自由振動解析により求めたウェットモード振動数とモード形を用 いて，モード合成法により水平地震動に対する応答解析を定式化す る。水平地震動に対する構造物の軸方向, 円周方向, および半径方 向応答変位成分は以下のように与えられる。

$$
\begin{aligned}
& u=\sum_{m=1}^{\infty} u_{m 1}(z) \operatorname{con} \theta q_{m 1}(t), \\
& v=\sum_{m=1}^{\infty} v_{m 1}(z) \sin \theta q_{m 1}(t), \\
& w=\sum_{m=1}^{\infty} w_{m 1}(z) \operatorname{con} \theta q_{m 1}(t),
\end{aligned}
$$

ここに, $u_{m 1}(z), v_{m 1}(z), w_{m 1}(z)$ はそれぞれ変位成分 $u, v, w の$ $m 1$ 次軸方向関数, $q_{m 1}(t)$ は $m 1$ 次一般化座標である。

地震時の構造物の応答は以下のラグランジェ方程式に支配され る。

$$
\frac{d}{d t}\left(\frac{\partial T}{\partial \dot{q}_{m 1}}\right)-\frac{\partial T}{\partial q_{m 1}}+\frac{\partial S}{\partial q_{m 1}}=Q_{D m 1}+Q_{A m 1}
$$

ここに, $Q_{D m 1}$ は構造物の材料減衰に関する $m 1$ 次一般化隇衰力, $Q_{A m 1}$ は $m 1$ 次一般化力であり次式で与えられる。

$$
\begin{aligned}
Q_{A m 1}= & \int_{0}^{d} \int_{0}^{2 \pi}\left\{p_{z} u_{m 1}(z) \cos \theta+p_{\theta} v_{m 1}(z) \sin \theta\right. \\
& \left.+\left(p_{r}+p_{w}\right) w_{m 1}(z) \cos \theta\right\} a d \theta d z
\end{aligned}
$$

式(34a c )を式(35) と(36)に代入し, ウェットモード形の直交性を利用す ると以下のモーダル運動方程式が得られる ${ }^{16)}$

$$
\begin{aligned}
& \left(M_{m 1}+M_{m 1}^{*}\right) \ddot{q}_{m 1}(t)+\left(C_{m 1}+C_{m 1}^{*}\right) \dot{q}_{m 1}(t)+K_{m 1} q_{m 1}(t) \\
& \quad=Q_{m 1}(t),
\end{aligned}
$$

ここに, $M_{m 1}, C_{m 1}$, および $K_{m 1}$ は構造物の $m 1$ 次一般化質量, 一 般化減衰, および一般化剛性, $M_{m 1}^{*}$ と $C_{m 1}^{*}$ は構造物と海水との相互作 用による $m 1$ 次一般化付加質量と一般化付加減衰， $Q_{m 1}(t)$ は $m 1$ 次 一般化力であり次式で与えらえる。

$$
\begin{aligned}
Q_{m 1}(t)= & \rho_{s} h \pi a \int_{0}^{l}\left\{-v_{m 1}(z)+w_{m 1}(z)\right\} d z \cdot \ddot{U}_{g}(t) \\
& +\int_{0}^{d} \int_{0}^{2 \pi} p_{R} w_{m 1}(z) \cos \theta a d \theta d z .
\end{aligned}
$$

正金井・田治見式で与えられる19)。

$$
\begin{aligned}
S \ddot{U}_{g} v_{s}(\sigma)= & S_{0}\left[\frac{1+4 \xi_{g}^{2}\left(\sigma / \omega_{g}\right)^{2}}{\left\{1-\left(\sigma / \omega_{g}\right)^{2}\right\}^{2}+4 \xi_{g}^{2}\left(\sigma / \omega_{g}\right)^{2}}\right] \\
& \cdot\left[\frac{\left(\sigma / \omega_{k}\right)^{4}}{\left\{1-\left(\sigma / \omega_{k}\right)^{2}\right\}^{2}+4 \xi_{k}^{2}\left(\sigma / \omega_{k}\right)^{2}}\right]:-\infty<\sigma<+\infty,
\end{aligned}
$$

ここに, 右辺の 1 番目の大カッコは金井・田治見のローパスフィ ル夕，2番目の大カッコは Clough・Penzienのハイパスフィルタで ある。また, $S_{0}$ はパワースペクトル強度, $\omega_{g}$ と $\xi_{g}$ はローパスフィル

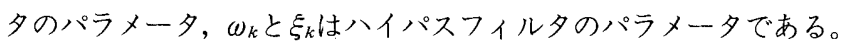

定常ランダム応答解析に基づき, 構造物の各変位成分の二乗平均 值は以下のように表せる。

$$
\begin{aligned}
& \bar{u}^{2}=\sum_{m=1}^{\infty} u_{m 1}^{2}(z) \cos ^{2} \theta \bar{q}_{m 1}^{2}, \\
& \bar{v}^{2}=\sum_{m=1}^{\infty} \nu_{m 1}^{2}(z) \sin ^{2} \theta \bar{q}_{m 1}^{2}, \\
& \bar{w}^{2}=\sum_{m=1}^{\infty} w_{m 1}^{2}(z) \cos ^{2} \theta \bar{q}_{m 1}^{2},
\end{aligned}
$$

ここに, $\bar{q}_{m 1}^{2}$ は $m 1$ 次一般化座標の分散であり次式で与えられる。

$$
\bar{q}_{m 1}^{2}=\int_{-\infty}^{+\infty}\left(M_{m 1}+M_{m 1}^{*}\right)^{2}\left(\alpha_{m 1}^{2}+\frac{\beta_{m 1}^{2}}{\sigma^{2}}\right)\left|H_{m 1}(\sigma)\right|^{2} S_{Q_{m 1} Q_{m 1}}(\sigma) d \sigma, \quad \text { (41) }
$$

ここに, $S_{Q_{m \mid Q m 1}}(\sigma)$ は一般化力 $Q_{m 1}(t)$ のパワースペクトル密度関 数, $\left|H_{m 1}(\sigma)\right|^{2}$ は $m 1$ 次伝達関数であり次式で与えられる。

$\left|H_{m 1}(\sigma)\right|^{2}=1 /\left(M_{m 1}+M_{m 1}^{*}\right)^{2}\left\{\left(\omega_{m 1}^{2}-\sigma^{2}\right)^{2}+4\left(\bar{\xi}_{m 1}+\bar{\xi}_{m 1}^{*}\right)^{2} \omega_{m 1}^{2} \sigma^{2}\right\} . \quad$ (42) また，係数 $\alpha_{m 1}$ と $\beta_{m 1}$ は次式で与えられる。

$$
\begin{aligned}
\alpha_{m 1}= & \left\{\rho_{s} h \pi a \int_{0}^{l}\left(-v_{m 1}(z)+w_{m 1}(z)\right) d z+\pi a \int_{0}^{d} m_{0}^{*}(z) w_{m 1}(z) d z\right\} \\
& /\left(M_{m 1}+M_{m 1}^{*}\right), \\
\beta_{m 1}= & \pi a \int_{0}^{d} c_{0}^{*}(z) w_{m 1}(z) d z /\left(M_{m 1}+M_{m 1}^{*}\right)
\end{aligned}
$$

ここに, $m_{0}^{*}(z)$ と $c_{0}^{*}(z)$ はそれぞれ動水圧成分 $p_{R}$ の加速度と速度 に同位相な成分の軸方向関数である ${ }^{20)}$ 。ただし，無水状態を除き $\beta_{m 1}$ $=0$ である。加速度成分は $\bar{q}_{m 1}^{2}$ 审 $\bar{m}_{m 1}^{2}$ 置きかえることにより求まる。

\section{7. 数值結果と検討}

有限な広がりを有する薄水盤に囲まれた中空円筒構造物の地震時 流力弾性応答を検討するために数值例題を示す。構造物の形状寸法 は, $l=80 \mathrm{~m}, a=20 \mathrm{~m}, h=0.2 \mathrm{~m}$ とする。構造物の材料定数は, $E$ $=2.0 \times 10^{11} \mathrm{~N} / \mathrm{m}^{2}, \mu=0.3, \rho_{s}=8.0 \times 10^{3} \mathrm{~kg} / \mathrm{m}^{3}$, 空中での減衰比は 各モードとも 0.02 とする。水盤の幅として $, b-a=0,10,20,40$, $80 \mathrm{~m}$ ，およびのの場合を考之る。すなわち，水盤のない完全な自由表 面の状態と水盤が無限に広がっている状態を雨極限として，水盤の 幅を 6 ケース設定する。 $b-a=0$ のときは文献 20$), b-a=\infty$ のとき は文献14)の方法により, 部分水のときは本研究の方法により解を求 める。水盤下の海水の質量密度は $\rho_{w}=1.02 \times 10^{3} \mathrm{~kg} / \mathrm{m}^{3}$ とする。式(25) の級数の項数は $N=7$ とする。水平地盤加速度のパワースペクトル密 度関数のパラメー夕值は，硬質地盤として $\omega_{g}=15.6 \mathrm{rad} / \mathrm{sec}, \xi_{g}=$ $0.6, \omega_{k}=1.0 \mathrm{rad} / \mathrm{sec}, \xi_{k}=0.6$ を採用し，スペクトル強度は $\mathrm{El}$ Centro $1940 \mathrm{NS}$ 成分に相当する $S_{0}=4.8 \times 10^{-3} \mathrm{~m}^{2} / \mathrm{sec}^{3} \mathrm{rad}$ とす $3^{19)}$ 。 
ウェットモード自由振動解析を行い, 水盤の幅がウェットモード 特性に与える影響を検討する。Fig. 4に, 水盤の幅をパラメータとし て, 梁モードのウェットモード振動数の設置水深による変化を軸方 向モード次数 $m=1 ， 2 ， 3$ 対して示す。一般に, 水盤の幅が大きい ほど動水圧の閉じこめ効果により付加質量が増加しウェットモード 振動数は低下している。しかし, 水盤の幅が比較的小さいうちから 無限水盤の場合の值に近づき, 水盤の幅が構造物の直径の 2 倍程度 になると各モードとも無限氷盤の場合の值に収束する傾向が見られ る。ウェットモード振動数は水盤の幅によらず 1 次モードでは水深 とともに緩やかに減少するが， $2 ， 3$ 次モードでは設置水深が浅い ときに急激な低下が生じている。すなうち，構造物の高さに比して 設置水深が浅い場合, 高次モードではドライモード振動数に対する ウェットモード振動数の変化は大きい。

Fig. 5に, 水盤の幅をパラメータとして, 設置水樑 $d / l=0.8$ のき の梁モードのウェットモード形の変化を軸方向モ一ド次数 $m=1,2$, 3に対して示す。1次モードでは氷盤の幅がモード形に与える影響は 極めて小さく，2，3次モードではその影響が見られるものの顕著 ではない。このことは,Fig. 4 の設置水深 $d / l=0.8$ とき, 水盤の幅 によるウェットモード振動数の変化が各モードとも比較的小さいこ とに対応している。

水平地震動を受けたときの地震応答解析を行う。設置水深は $d / l$ $=0.8$ とする。Fig. 6に, 水平地盤加速度のパワースペクトルと無水 状態と全水状態のときの梁モードのウェットモード振動数の関係を 示す。両状態とも 1 次モードのウェットモード振動数は水平地盤加 速度のパワースペクトルの主要領域に入っているが，2次以上の高 次モードの固有振動数は主要領域から大きく離れている。なお, 式 (41)の振動数領域における数值積分は, 積分領域を $0 \sim 70 \mathrm{rad} / \mathrm{sec}$, 分 割数を 200 とし，Simpson 則を用いて行った。

Fig. 7に, 水平地震動を受けたときの海水の幅による動水圧分布 の変化を示す。構造物の岡体運動による動水圧成分, 弾性変形によ る動水圧成分，抢よび両者の和としての全動水圧を rms 值として求 めた。剛体運動による動水圧成分は水盤の幅が小さいと海底から海 面に向けて単調に減少するが，氷盤の幅が大きくなるにつれて海面 付近の動水圧が増加し, 水盤の幅が無限大になると動水圧分布は深 さ方向に一定の值となる。弾性変形による動水圧成分は氷盤の幅が 大きくなるにつれ海底から海面までの全領域で増加する。全動水圧
に占める割合は弾性変形による動水圧成分が阙体運動による動水圧 成分に比べて支配的である。氷盤の幅が構造物の直径の 2 倍程度に なると無限氷盤のときの值にほぼ収束しており, 水盤の幅が比較的 小さくても大きな動水圧の関じ込好効果を有することが確認でき る。

Fig. 8に水平地震動を受けたときの水盤の幅による相対変位と相 対加速度の $\mathrm{rms}$ 応答の変化を示す。定式化で示したように，洞体運 動による動水圧成分の増加は荷重項の増加となり, 弾性変形による 動水圧成分の増加は付加質量の増加となってウェットモード振動数 を減少させる。前者は必ず応答を增幅させるが, 後者は地震動の周 波数特性に応じて応答を増加させる場合もあれば減少させる場合も ある。本例題では, Fig. 6に示したように，氷盤の幅が大きくなると $m=1$ のエットモード振動数が水平地盤加速度のパワースペクト ルの主要領域に近づき，相対変位は徐々に增加している。水盤の幅 が構造物の直径の 2 倍程度になると無限水盤のときの值にほぼ収束 している。一方, 相対加速度は 2 次モードの影響等により忘答の增 減の傾向が明確ではないが, 水盤の幅に関わらず概ね似たような結

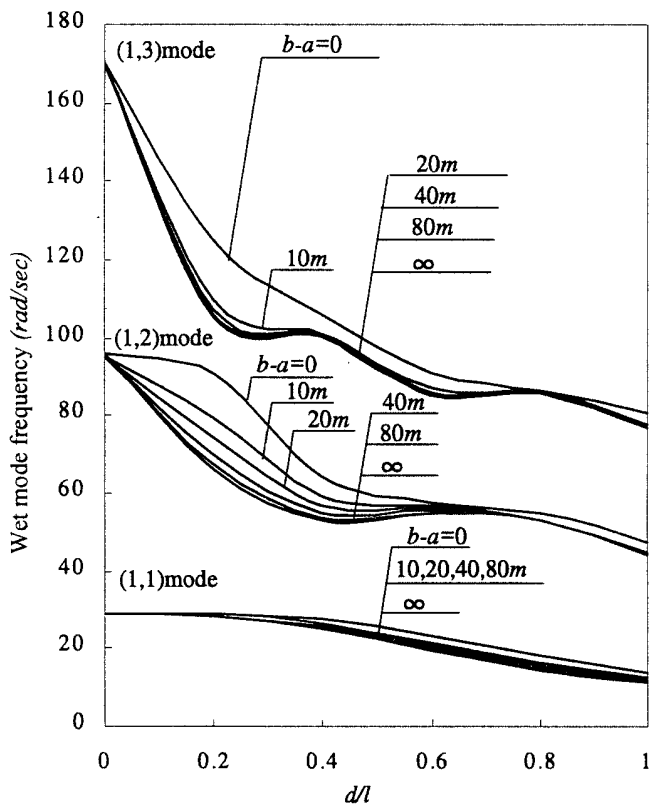

Fig. 4 Change in wet mode frequencies due to ice width

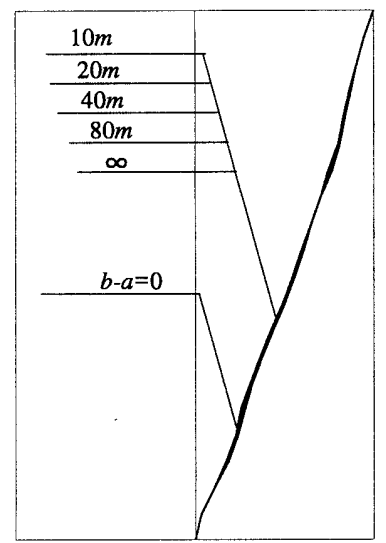

1st mode

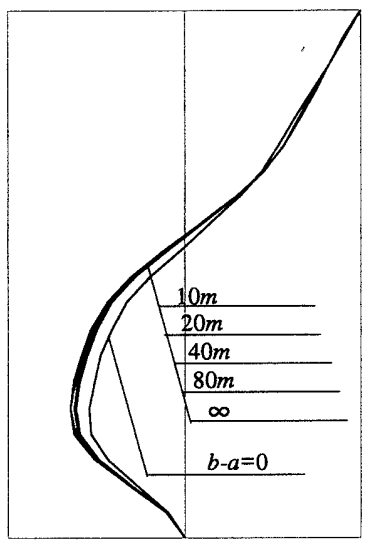

2nd mode

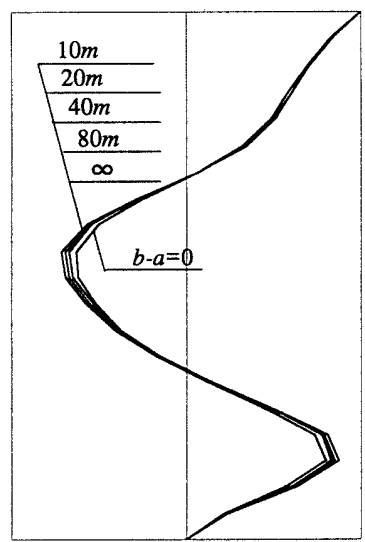

3rd mode

Fig. 5 Change in wet mode shapes due to ice width 
果になっており水盤の幅の影響は小さい。
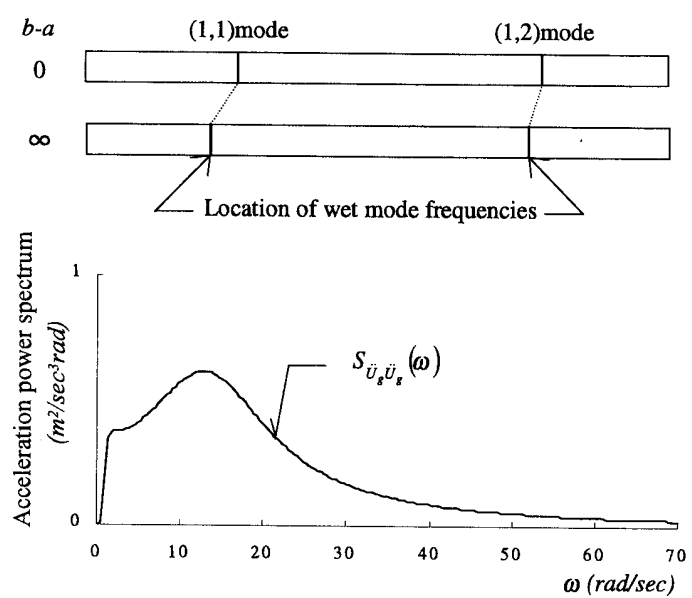

Fig. 6 The location of wet mode frequencies with and without sea ice in the frequency domain

\section{8. 結び}

水海構造物の設計は, 水荷重に対しては長年の研究とデー夕の蓄 積に基づきかなり整储されてきている。しかし，耐震設計となると， 最近注目されてはいるものの, 今後の展開に期待するところが大き いというのが実状である。氷海構造物の耐震設計を整備していくた めには, 地震荷重と地震応答に関する実海域デー夕の蓄積とともに, 今後も解析と実験による研究の成果を積み重るていく必要がある。

水海構造物の耐震設計は, 水のない海洋構造物の耐震設計を基本 として, 氷盤が存在することによる地震時の影響を取り込むという 方向が妥当と思われる。承盤の影響は, 水盤による地震荷重の増幅 効果と構造物と水盤の相互作用効果に大別できる。両効果とも構造 物と水盤の幾何学的特性と材料特性に依存する。本研究では, 薄水 盤の仮定を設けることにより相互作用効果を無視し, 荷重増幅効果 を数理モデルにより評価した。

有限な広がりを有する薄水盤に囲まれた固定式中空円筒構造物を 対象として, 水平地震動を受けるときの動水圧分布と応答挙動を求 める解析的手法を示した。また, 水盤の幅をパラメー夕としてウェッ トモード特性と動水圧抢よび地震応答への影響を検討した。本研究
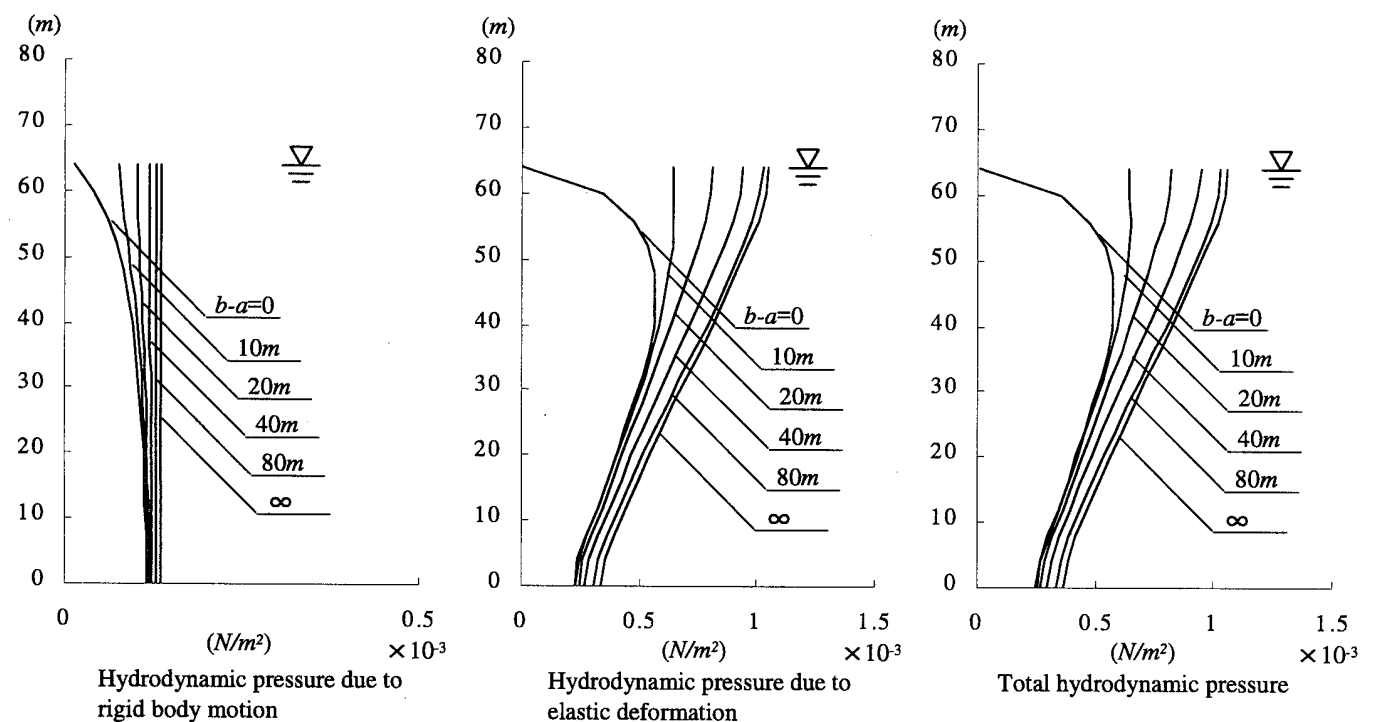

Fig. 7 Change in hydrodynamic pressure distributions due to ice width
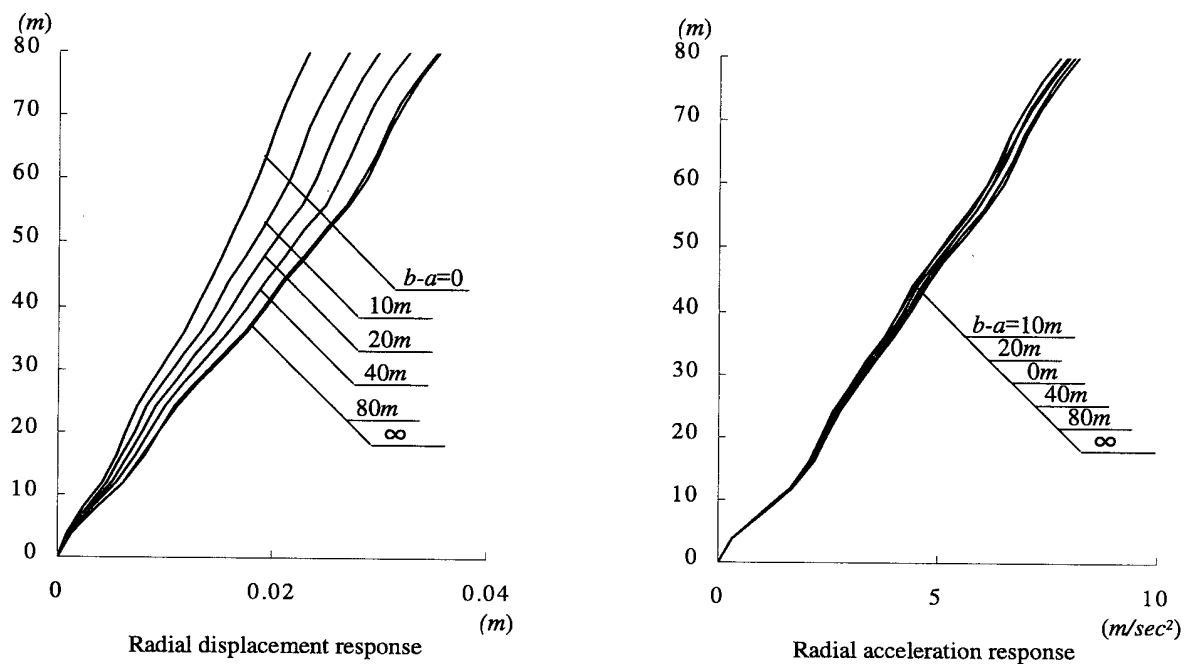

Fig. 8 Change in structural response distributions due to ice width 
の範囲内で得られた知見を以下に要約する。

1) 周囲に水盤がある場合のウェットモード振動数は一般に設置水 深とともに単調減少する。1次モードでは設置水深の増加ととも に緩やかに減少する傾向を示すが, 高次モードになると構造物の 高さに対する設置水深の比が小さい場合に急激な減少を示し, 設 置水深が増加すると変化は小さくなる。

2）構造物周辺の水盤の偪が大きいほど, 動水圧の閉じこめ効果に より付加質量は増加し, ウェットモード振動数の減少量が大きく なる。しかし, 水盤の幅が比較的小さなうちにその減少傾向は止 まり，各モ一ドとも氷盤の幅が構造物の直径の 2 倍程度になると 無限水盤の場合の值に収束する傾向が見られる。

3 ）構造物のウェットモード形も水盤の幅の影響を受ける。しかし, 構造物の高さに対する設置水深の比が大きな場合には，1 次モ一 ドでは氷盤の幅の影響をほとんど受けず，高次モードになっても わずかに変化が生じる程度である。

4) 水平地震動が作用したときに生じる動水圧は，構造物の岡体運 動による動水圧成分に比べ弾性変形による動水圧成分が支配的に なる。したがって，構造物に変形が生じる場合には流力弾性解析 が不可欠である。

5 ）水盤の幅が大きくなると, 閉じ込め効果により剛体運動と弾性 変形による動水圧成分はともに増加するが，氷盤の幅が構造物の 直径の 2 倍程度になると無限永盤の場合の值に収束する傾向を示 す。

6 ）定式化を通じて, 弾性変形による動水圧成分の増加は付加質量 の増加として，剛体運動による動水圧成分の増加は荷重項の増加 として評価されることを示した。付加入力の増加は常に応答を増 加させるが, 付加質量の増加は入力地震動のスペクトル特性に応 じて応答を増幅させる場合もあれば減少させる場合もある。構造 物の変位応答は氷盤の幅とともに変化し, 水盤の幅が構造物の直 径の 2 倍程度になると無限水盤のときの値に収束する傾向を示 す。一方，加速度応答は氷盤の幅に大きくは依存しない傾向が見 られる。

水海構造物の耐震設計は, 構造物と水盤と海水と地盤が連成する 複雑な現象を対象としている。この連成系を数值解析により直接扱 うことも考えられるが，モデルパラメータが極めて多くなり，数值 結果に基づいて耐震設計のための設計式を導くことは難しい。この ような場合, 複雑な問題を単純な要素問題に分割し，それぞれの要 素問題の一般的傾向を把握し, 最後に各結果を統合して設計式を導 くことが有効な場合がある。本研究で扱った問題は, 水海構造物の 耐震設計に関連した一つの要素問題であり, 水盤の幅をパラメータ
として荷重增幅効果とその流力弾性応答への影響を評価することを 目的としている。今後も新たな要素問題を整理・発掘し，その理論 的あるいは実験的研究から得られた成果を統合することにより，水 海構造物の耐震設計を整備していくことが望まれる。

\section{参考文献}

1）青田昌秋：白い海·凍る海 オホーツク海のふしぎ,東海大学出版会, 1993

2) API : Recommended Practice for Planning, Designing, and Constructing Structures and Pipelines for Arctic Conditions, 1995

3）寒地港湾技術研究センター：水海域における海岸・海洋構造物設計マニュ アル, 1996

4) Bennett, F.L.; Machemehl, J.L.(eds.) : Civil Engineering in the Arctic Offshore, ASCE, 1985

5) Enkvist, E., Eranti, E. : Development of Arctic Offshore Technology, Technology Development Center TEKES, 1990

6）瀬野徹三：日本付近のプレート運動と地震, 科学, No. 66, pp.711-719, 1993

7) Kato, K. et al.: Ice and Earthquake Loads on a Structure in the Okhotsk Sea: Annual Report of the JOIA Project, FY1998, Proc. of the $10^{\text {th }}$ Int. Offshore and Polar Engrg. Conf., Vol. 1, pp.545-551, 2000

8) Kobayashi, H., Kawaguchi, H.: Evaluation of Seismic Load on Offshore Structure in Ice-Covered Waters, Proc. of the $10^{\text {th }}$ Int. Offshore and Polar Engrg. Conf., Vol. 1, pp.674-678, 2000

9) Caidwell, S.R., Crissman, R.D.(eds.): Design for Ice Forces, ASCE, 1983

10) Maattanen, M.: Ice Forces, in Offshore Structures, Vol.1, Krieger Pub., pp.149-159, 1991

11) Croteau, P.: Dynamic Interactions Between Floating Ice and Offshore Structures, Report No. UCB/EERC-83/06, Earthquake Engineering Research Center, Univ. of California, 1983

12）安達 洋, 中西三和ほか：水海域における構造物の地震応答に関する研究 （その1〜17），日本建築学会大会学術講演梗概集，1987 96

13）清川哲志, 黑川 明, 川口靖博：水海構造物の地霞時動水圧解析, 第14回 海洋工学シンポジウム論文集, 日本造船学会, pp. 187〜194, 1998

14）濱本卓司，大西弘亮，井上昌志，田中弥寿雄：水海域に抢ける叮筒シェル の地震応答, 構造工学論文集, 日本建築学会, Vol. 46B, pp.135-140, 2000

15）森田知志。西坦 亮，小林 浩：水盤に閉ざされた重力式海洋構造物まわ りの地震時動水圧の特性, 海洋開発論文集, 土朴学会, Vol. 15, pp.571-576, 1999

16) Hamamoto, T., Inoue, M., Tanaka, Y.: Seismic Analysis of Vertical Cylindrical Towers in Ice-Covered Seas, Proc. of the 12th WCEE, Paper No. 1071, 2000

17）濱本卓司,田中彌壽雄：固定式海洋円筒シェルの動的解析 その 1 ：固有 振動解析, 日本建築学会論文報告集, 第291号, pp.129 141, 1980.5

18) Novozhilov, V.V.: Thin Shell Theory, Wolters-Noordhoff Pub., 1970

19) Clough, R.W., Penzien, J.: Dynamics of Structures, McGraw.Hill, 1975

20）濱本卓司, 田中彌壽雄：固定式海洋网简シェルの動的解析 その 3 ：地震 応答解析，建築学会論文報告集，第303号，pp.141-154，1981.5

(2000年 7 月 10 日原稿受理，2000年11月15日採用決定） 